\title{
Bilateral femoral neck insufficiency fractures in pregnancy
}

\author{
Gebelikte çift taraflı femur boyun yetersizlik kırığı \\ Mehmet Emre Baki, M.D., Hüseyin Uygun, M.D., Bünyamin Arı, M.D., Hafız Aydın, M.D. \\ Department of Orthopedics and Traumatology, Medical Faculty of Karadeniz Teknik University, Trabzon, Turkey
}

\begin{abstract}
Bilateral femoral neck insufficiency fracture due to osteomalacia in pregnancy is an extremely rare condition. In this article, we report a 22-year-old female case with bilateral femoral neck fractures in whom the diagnosis was delayed due to the avoidance of ionising radiation and managing hip complaints by conservatively in pregnancy. She was treated surgically with internal fixation using cannulated screws and received medical treatment for vitamin D deficiency.
\end{abstract}

Key words: Femoral neck fracture; osteomalacia; pregnancy.
Gebelikte osteomalaziye bağlı iki taraflı femur boyun yetersizlik kırı̆̆ı çok nadir görülen bir durumdur. $\mathrm{Bu}$ yazıda gebelikte iyonize radyasyondan kaçınılması ve kalça yakınmalarının konservatif olarak tedavi edilmesi nedeniyle geç tanı konulan iki taraflı femur boyun kırı̆̆ı olan 22 yaşında bir kadın olgu sunuldu. Hastaya cerrahi olarak kanüllü vidalar yardımıyla internal tespit uygulandı ve vitamin D eksikliği için de tıbbi tedavi verildi.

Anahtar sözcükler: Femur boyun kırı̆̆ı; osteomalazi; gebelik.

her third pregnancy while she was breastfeeding her second child. She had no history of trauma and systemic disorder.

On physical examination, external and internal rotations of both hips were painfully restricted and she had inability in walking without crutches. Her body mass index was 21. (height: $160 \mathrm{~cm}$; weight: $58 \mathrm{~kg}$ ). The radiograph showed fractured lines of both femoral necks (Figure 1). Magnetic resonance imaging (MRI) was confirmed bilateral femoral neck insufficiency fractures. Her lumbar spine bone mineral density (BMD) was reduced to $0.80 \mathrm{gr} / \mathrm{cm}^{2}$ and femoral BMD was reduced to $0.52 \mathrm{gr} / \mathrm{cm}^{2}$. Lumbar spine $\mathrm{T}$ score was reduced to -2.59 and femoral neck $\mathrm{T}$ score was reduced to -3.78 . Her laboratory investigations were as follows: calcium (Ca): $8.3 \mathrm{mg} / \mathrm{d} 2$ (8.8-10.6), inorganic phosphate $(\mathrm{P})$ : $2.1 \mathrm{mg} / \mathrm{d} 2$ (2.5-4.5), intact parathormone (IPTH): $374 \mathrm{pg} / \mathrm{ml}$ (12-69), alkaline phosphatase (ALP): $332 \mathrm{U} / \mathrm{L}$ (0-270), 25-hydroxyvitamin D3: $3.2 \mathrm{mg} / \mathrm{L}$ (10$50)$, and 24 hour urine calcium excretion: $3 \mathrm{mg} / \mathrm{dL}$ (6.721.3). According to the laboratory findings, diagnosis

- Received: February 18, 2014 Accepted: February 22, 2014

- Correspondence: Mehmet Emre Baki, M.D. Karadeniz Teknik Üniversitesi Tıp Fakültesi Ortopedi ve Travmatoloji Anabilim Dalı, 61000 Trabzon, Turkey. Tel: +90462 - 3775660 Fax: +90462 - 3214153 e-mail: bakiemre61@yahoo.com 


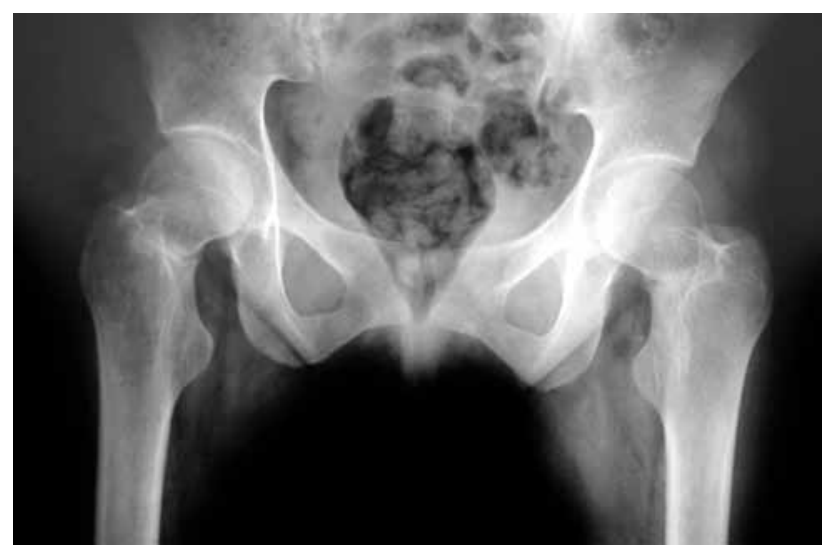

Figure 1. Bilateral femoral neck insufficiency fractures.

of vitamin D deficiency and osteomalacia were established. The informed consent of the patient was obtained.

Fractures were treated with internal fixation using cannulated screws and medical treatment including the therapeutic doses of vitamin D3 and calcium was started. She started to walk with crutches 45 days after operation. At the latest follow-up six months postoperatively, the patient performed normal daily activities and had no pain. 25-hydroxyvitamin D3 levels were increased to: $32.6 \mathrm{mg} / \mathrm{L}$ (10-50), Ca: $9.4 \mathrm{mg} / \mathrm{dL}$ (8.8-10.6), P: $3.3 \mathrm{mg} / \mathrm{dL}$ (2.5-4.5) and IPTH: 65 (12-69): The BMD of lumbar spine increased to $0.88 \mathrm{gr} / \mathrm{cm}^{2}$. Lumbar spine $\mathrm{T}$ score was increased to -1.88 .

\section{DISCUSSION}

Bilateral femoral neck insufficiency fractures due to osteomalacia in pregnancy are extremely rare conditions. We find only one case in the literature. ${ }^{[5]}$ Neural compressions and musculoskeletal complaints are very common in pregnancy. Mostly, these complaints are not serious and can be treated conservatively. ${ }^{[6]}$

Osteomalacia is a metabolic bone disease characterized by insufficient mineralization of bone matrix. Vitamin D deficiency is the most frequent reason of osteomalacia. Long-term vitamin D deficiency may lead to muscle weakness, increasing the risk for insufficiency fractures. ${ }^{[7]}$

During pregnancy and lactation, infants drive their vitamin $\mathrm{D}$ and calcium from maternal stores. In lactation, calcium demand mobilized from maternal skeleton. ${ }^{[2,3,8]}$ Continuous multiple pregnancies and extended lactations such as in this case can be promote the maternal vitamin $\mathrm{D}$ and calcium loss. Women with insufficient sunlight for cultural and religious

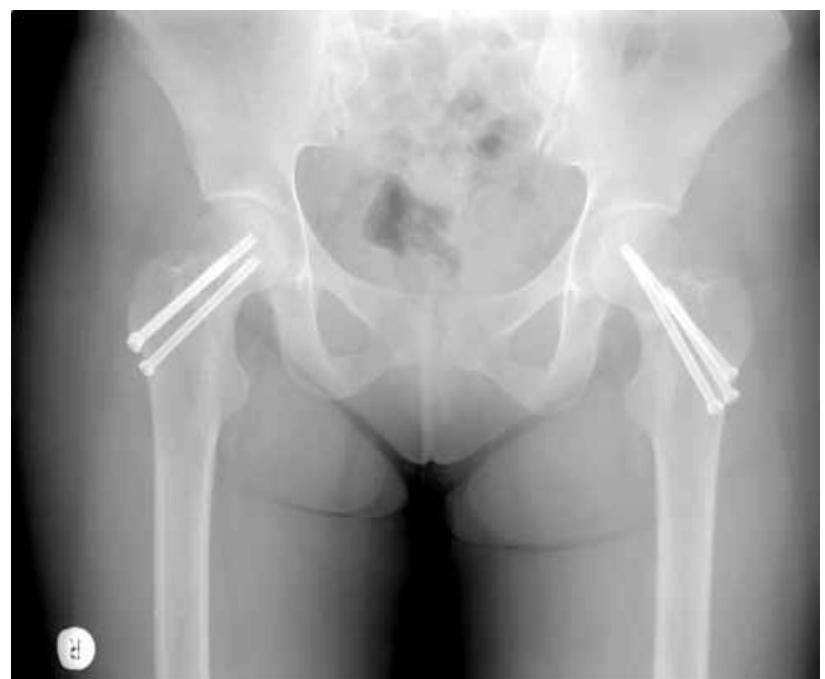

Figure 2. Complete healing at the recent follow-up at six months postoperatively.

reasons are prone to the vitamin D efficiency. ${ }^{[5]}$ In our case, the patient wears full purdah (only face and hands are exposed in public); this may increase the severity of bone loss.

Avoiding ionising radiation for imaging may have delayed the serious specific diagnosis. However, increasing and persistent hip pain during the third trimester of pregnancy should alert the health care workers for an insufficiency fracture which can be treated with surgical and medical treatment including vitamin D and calcium supplementation. Vitamin D3 is the preferred choice. ${ }^{[7]}$

\section{Declaration of conflicting interests}

The authors declared no conflicts of interest with respect to the authorship and/or publication of this article.

\section{Funding}

The authors received no financial support for the research and/or authorship of this article.

\section{REFERENCES}

1. Bringhurst FR, Demay MB, Krane SM, Kronenberg HM. Bone and mineral metabolism in health and disease. In: Fauci AS, Braunwald E, Kasper DL, Hauser SL, Longo DL, Jameson JL, et al, editors. Harrison's principles of internal medicine. 17th ed. New York: McGraw Hill Medical; 2008. p. 2366-77.

2. Eisman J. Relevance of pregnancy and lactation to osteoporosis? Lancet 1998;352:504-5.

3. Ritchie LD, Fung EB, Halloran BP, Turnlund JR, Van Loan $\mathrm{MD}$, Cann CE, et al. A longitudinal study of calcium homeostasis during human pregnancy and lactation and after resumption of menses. Am J Clin Nutr 1998;67:693-701. 
4. Laskey MA, Prentice A, Hanratty LA, Jarjou LM, Dibba $\mathrm{B}$, Beavan SR, et al. Bone changes after 3 mo of lactation: influence of calcium intake, breast-milk output, and vitamin D-receptor genotype. Am J Clin Nutr 1998;67:685-92.

5. Henry A, Bowyer L. Fracture of the neck of the femur and osteomalacia in pregnancy. BJOG 2003;110:329-30.

6. Kalender AM, Dogan A, Cakar A, Turkoz T. Neglected bilateral femoral neck fracture associated with pregnancy and primary hyperparathyroidism. Acta Orthop Belg 2010;76:559-63.

7. Atik OS. Is vitamin D2 better than vitamin D3? Eklem Hastalik Cerrahisi 2012;23:61.

8. McAree T, Jacobs B, Manickavasagar T, Sivalokanathan S, Brennan L, Bassett P, et al. Vitamin D deficiency in pregnancy - still a public health issue. Matern Child Nutr 2013;9:23-30. 